\title{
KEMANDIRIAN EMOSIONAL PADA REMAJAAWAL: STUDI DI SMPN 1 MARGAASIH KABUPATEN BANDUNG
}

\author{
Aulia Nurul Husna S.Psi dan Esti Wungu, M.Ed., Psikolog \\ Fakultas Psikologi Universitas Padjadjaran \\ E-mail: aulia14014@mail.unpad.ac.id
}

\begin{abstract}
ABSTRAK, Remaja yang belum memiliki kemandirian emosional sesuai dengan usianya, dikhawatirkan akan mengalami kesulitan dalam mendapatkan identitas diri yang jelas. Hal ini karena kemandirian emosional penting bagi individu, terutama pada remaja awal karena kemandirian emosional ini menunjukkan proses kematangan individu dalam mempersiapkan diri menuju dewasa. Tujuan dari penelitian ini adalah untuk mendapatkan data empirik mengenai gambaran kemandirian emosional pada siswa SMPN 1 Margaasih Kabupaten Bandung. Penelitian ini dilakukan terhadap 290 siswa (remaja awal) SMPN 1 Margaasih Kabupaten Bandung. Rancangan penelitian yang digunakan adalah non eksperimental kuantitatif dengan metode deskriptif menggunakan alat ukur berupa kuesioner tentang kemandirian emosional, yang mengacu pada teori Steinberg. Hasil penelitian menunjukkan sebagian besar siswa SMPN 1 Margaasih Kabupaten Bandung memiliki kemandirian emosional yang tergolong tinggi. Artinya, mereka sudah mampu memandang orang tuanya bukan sebagai sosok yang paling tahu mengenai kehidupan dan perasaan remaja. Mampu memandang dan berinteraksi dengan orang tua sebagai orang dewasa lainnya yang memiliki berbagai peran. Dapat bergantung pada kemampuan dirinya sendiri tanpa mengharapkan bantuan orang tua ketika menyelesaikan masalah. Serta memiliki sesuatu yang pribadi yang tidak selalu harus diketahui oleh orang tua (proses individuasi) dan dapat bertanggung jawab atas dirinya.
\end{abstract}

Kata kunci: kemandirian emosional; remaja awal; siswa

\section{EMOTIONAL AUTONOMY IN EARLY ADOLESCENTS: STUDY AT SMPN 1 MARGAASIH, BAND- UNG REGENCY}

\begin{abstract}
Teenagers who were still relying on their parents and also have the lack of an autonomy according to their age, were feared to have difficulty in getting a true identity. This is important because emotional autonomy is essentials for every individual, especially in adolescents because the emotional autonomy showed the maturity process of individuals in preparing themselves for their maturity. The purpose of this study was to obtain empirical data regarding the description of emotional autonomy in students of SMPN 1 Margaasih, Bandung Regency. The number of participants used in this study amounted to 290 students. The research design used was a quantitative non-experimental approach with quantitative descriptive methods. The results showed that the majority students of SMPN 1 Margaasih Bandung Regency had high emotional autonomy. That is, they are able to see their parents not as the person who knows most about the life and feelings of teenagers. Able to view and interact with parents as other adults who have various roles. Can depend on his own abilities without expecting help from parents when solving problems. As well as having something personal that does not always have to be known by parents (individuation process) and can be responsible for themselves.
\end{abstract}

Key words: Emotional autonomy; early adolescence; student

\section{PENDAHULUAN}

Masa remaja merupakan masa di mana terjadinya transisi dari masa ketidakmatangan anak-anak menuju kematangan di masa dewasa (Santrock, 2014). Dalam masa remaja tersebut terdapat beberapa tugas-tugas perkembangan yang harus dipenuhi. Tugas-tugas perkembangan pada masa remaja menurut Santrock (2007) adalah mencapai hubungan baru dan yang lebih matang dengan teman sebaya, baik pria maupun wanita, mencapai peran sosial sesuai dengan jenis kelamin, pria atau wanita, menerima keadaan fisiknya dan memanfaatkan dengan efektif, mampu dan mencapai perilaku sosial yang bertanggung jawab, mencapai kemandirian emosional terhadap orang tua dan orang-orang dewasa lainnya, mempersiapkan karier ekonomi, mempersiapkan perkawinan dan kehidupan keluarga, serta mengembangan sistem nilai dan etika sebagai pegangan dalam berperilaku mengembangkan ideologi.

Remaja juga dituntut untuk mampu menghadapi berbagai permasalahan, seperti masalah yang menyangkut pertumbuhan jasmani, hubungan dengan orang tua, agama, masa depan, dan sosial. Di mana pada masa ini perhatian remaja terhadap kedudukannya dalam masyarakat sangat besar, remaja ingin selalu diterima oleh kawan-kawannya, kemudian remaja dapat menyelesaikan masalah tersebut secara mandiri. Hal ini sesuai dengan salah satu tugas perkembangan remaja menurut Steinberg (2014), yaitu mengenai perkembangan kemandirian (autonomy), yang merupakan kemampuan remaja untuk mengatur dirinya sendiri dan mengekspresikan perilaku dengan tidak bergantung pada orang lain, baik secara emosional, perila$\mathrm{ku}$, dan nilai.

Kemandirian menurut Steinberg (2014) terdiri dari tiga aspek, yaitu kemandirian emosional, kemandirian perilaku, dan kemandirian nilai. Kemandirian emosional merupakan aspek kemandirian yang berhubungan dengan perubahan kedekatan individu dengan orang lain, terutama orang tua (Steinberg, 2014). Individu pada fase remaja tidak lagi bergantung kepada orang tuanya ketika membutuhkan bantuan. Remaja tidak lagi menganggap orang tua 
mereka sebagai sosok yang serba tahu (all knowing) atau berkuasa penuh atas kehidupan anaknya (all powerfull). Individu memiliki hubungan emosional dengan orang lain selain orang tuanya, seperti teman atau pacar.

Kemandirian perilaku merupakan kemampuan untuk mengambil keputusan secara mandiri dan bertanggung jawab atas pilihan yang diambil (Steinberg, 2014). Seorang remaja mengambil keputusan berdasarkan pertimbangan dari alternatif penyelesaian masalah dari beberapa sudut pandang kemudian membandingkan alternatif tersebut. Selain itu, remaja juga mempertimbangkan konsekuensi-konsekuensi yang akan muncul dari keputusan yang ia pilih. Kemandirian nilai merupakan pengembangan suatu keyakinan yang akan membimbing pemikiran dan perilaku seseorang tentang benar dan salah (Steinberg, 2014). Selain itu, keyakinan mereka juga didasari oleh prinsip-prinsip yang dapat dipertanggungjawabkan. Keyakinan seorang remaja juga tidak hanya didasari dari nilai yang diberikan oleh orang tua atau peran otoritas lain, tetapi didasarkan pada nilai dari dalam diri mereka sendiri (Steinberg, 2014).

Pada saat memasuki fase masa remaja, individu diharapkan mampu mengembangkan tugas kemandirian secara bertahap, diawali mengembangkan aspek kemandirian emosional terlebih dahulu. Apabila individu sudah mampu mengembangkan kemandirian emosional, individu dapat mengembangkan kemandirian perilaku dan kemandirian nilai sehingga individu dapat dikatakan mampu menyelesaikan tugas perkembangannya di masa remaja (Steinberg, 2014).

Tugas kemandirian emosional ini penting bagi remaja karena kemandirian emosional ini menunjukkan proses kematangan individu dalam mempersiapkan diri menuju dewasa. Individu akan dengan mudah menyesuaikan diri ketika menghadapi tuntutan dari lingkungannya di masa dewasa jika individu mampu mengembangkan kemandirian emosionalnya di masa remaja. Menurut Steinberg (2002), perkembangan kemandirian emosional dimulai pada awal masa remaja dan ketergantungan remaja terhadap orang tua akan berkurang pada remaja akhir.

Kemandirian emosional menitikberatkan pada perubahan hubungan individu yang awalnya dekat dengan orang tua perlahan-lahan mulai berkurang. Individu yang awalnya selalu bergantung pada orang tua, kini secara emosional mulai berusaha untuk mengurangi rasa ketergantungan tersebut dengan menunjukkan kebebasannya sendiri. Pada fase remaja, individu tidak tertarik lagi melakukan aktivitas bersama orang tua, tidak mau mendengarkan nasehat atau kritik dari orang tua, dan ikatan emosional dengan orang tua tidak lagi sedekat waktu masih anak-anak (Santrock, 2014). Menurut Steinberg (2014) kemandirian emosional remaja terdiri atas empat dimensi, yaitu: 1) de-idealized (memandang orang tua bukan sebagai sosok yang ideal), 2) parents as people (memandang orang tua sebagai orang dewasa pada umumnya), 3) non-dependency (tidak selalu bergantung pada orang tua dalam menyelesaikan masalah, 4) individuation (bagaimana individu memandang dirinya sendiri).

Penelitian sebelumnya menunjukkan bahwa awal masa remaja merupakan waktu yang penting untuk mengembangkan kemandirian emosional dalam hubungan keluarga dan teman sebaya (Hartup, 1983; Youniss \& Smollar, 1985, dalam Steinberg, 1985). Menurut David Elkind dalam Santrock (2007), remaja awal (early adolescence) adalah individu yang berada pada rentang usia 12-15 tahun dan pada umumnya usia tersebut merupakan individu yang sedang menjalani masa Sekolah Menengah Pertama (SMP).

Sejak kecil individu sudah dihadapkan pada berbagai pilihan. Semasa kanak-kanak, individu saat itu masih dihadapkan pada pilihan-pilihan yang sederhana dengan alasan pemilihan yang lebih berdasarkan kesukaan. Pada masa ini, individu akan dibantu dalam menentukan pilihan oleh orang tua. bahkan tidak jarang orang tua akan membuat keputusan bagi anaknya tanpa mendiskusikannya terlebih dahulu.

Semakin bertambahnya usia, alasan yang mendasari individu menentukan suatu pilihan akan semakin kompleks dengan berbagai macam faktor yang harus disertakan dalam pertimbangan sebelumnya (Santrock, 2014). Remaja awal dengan berbagai perubahan yang terlihat akan diajarkan untuk mulai menentukan keputusan tanpa atau bantuan yang seminimal mungkin dari orang tua atau orang dewasa lainnya dan remaja diharapkan dapat belajar mempertanggungjawabkan keputusannya. Apalagi, remaja awal yang berstatus sebagai siswa SMP umumnya mulai lebih banyak menghabiskan waktu jauh dari pengawasan langsung orang tua, sebab siswa SMP memiliki tugas perkembangan lain yang harus dijalani dan juga dikembangkan, seperti bersekolah untuk menuntut ilmu pengetahuan serta mengembangkan kemampuannya bersosialisasi dengan teman-teman.

Terdapat penelitian sebelumnya yang dilakukan oleh Nur Afni (2015) yang berjudul "kemandirian emosional remaja usia 12-15 tahun berdasarkan tipe pola asuh orang tua", menunjukkan bahwa beberapa responden mengungkapkan mereka melihat orang tua sebagai sosok yang selalu benar karena orang tua adalah orang yang mengetahui segala sesuatu, terutama suatu hal yang tang terbaik untuk anaknya, misalnya ketika memilih sekolah lanjutan, kemudian remaja menuruti saran dan pilihan sekolah dari orang tua. Kemudian responden juga mengatakan ketika mereka menghadapi masalah, misalnya bertengkar dengan teman, mereka akan menceritakan permasalahan tersebut kepada orang tua atau teman dekat mereka untuk meminta saran agar keluar dari permasalahan tersebut. Kemudian orang tua mereka pun akan memberi saran dan remaja akan mengikuti saran dari orang tuanya. Dan hal ini kurang sesuai dengan aspek non-dependency pada teori Steinberg (2014).

Remaja awal yang yang berstatus siswa SMP masih memandang orang tuanya sebagai orang paling ideal, yang mengetahui segala sesuatu sehingga dapat membuat kebi- 
jakan yang tepat. Hal ini memungkinkan sulitnya siswa SMP menerima kesalahan yang ternyata dapat dilakukan orang tuanya. Pada remaja yang masih pada tingkat SMP, biasanya peraturan masih sepenuhnya dibuat oleh orang tua dan anak masih memiliki ketakutan untuk menyatakan pendapatnya pada orang tua karena otoritas orang tua.

Remaja awal dengan status siswa SMP masih sangat bergantung kepada orang tua di dalam menentukan keputusan, terlebih mengenai perencanaan masa depan, seperti sekolah dan bidang pendidikan yang diminati. Kemudian, siswa SMP masih memiliki bayangan ketika masa kecil yang melihat orang tua sebagai sosok yang ideal sehingga banyak siswa SMP yang memiliki cita-cita sama seperti orang tuanya, dan bahkan mencoba menjadi sama seperti orang tuanya dalam segala hal. Selain itu, siswa SMP akan memberitahu segala permasalahan yang dihadapinya kepada orang tua karena anggapan bahwa orang tua merupakan sosok yang paling tahu mengenai hal-hal yang harus dilakukan, atau bahkan dapat langsung menyelesaikan masalah yang dihadapi remaja.

Menurut Conger (1991) dalam Permana, (2011:3), remaja yang masih bergantung pada orang tua dan belum memiliki kemandirian sesuai dengan usianya, remaja akan mengalami kesulitan dalam mendapatkan identitas diri yang jelas seperti mengejar pekerjaan dengan rasa percaya diri serta membangun hubungan heteroseksual. Kemudian hal ini juga tidak sesuai dengan tugas perkembangan pada masa remaja menurut Hurlock (2001), yaitu mencapai kemandirian emosional dari orang tua dan orangorang dewasa lainnya. Karenanya, peneliti tertarik untuk meneliti lebih lanjut "Bagaimana gambaran kemandirian emosional remaja pada siswa SMPN 1 Margaasih Kabupaten Bandung?"

\section{METODE}

Penelitian ini menggunakan pendekatan non-eksperimental kuantitatif dengan metode deskriptif. Pendekatan non-eksperimental penelitian empirik sistematis di mana peneliti tidak dapat mengontrol variabel bebas secara langsung karena menifestasinya telah muncul atau karena sifat variabel tersebut menutup kemungkinan terjadinya manipulasi (Kerlinger, 2006). Sementara penelitian kuantitatif adalah penelitian yang mengumpulkan beberapa data numerik untuk menjawab pertanyaan penelitian. Sedangkan metode deskriptif merupakan penggambaran sebuah fenomena, kejadian, atau situasi secara akurat (Christensen, 2007).

Karakteristik sampel dari penelitian ini adalah siswa SMPN 1 Margaasih Kabupaten Bandung, kelas 7, 8, dan 9. Dalam penelitian ini, teknik sampling yang digunakan adalah probability sampling dalam bentuk stratified random sampling. Proses pengambilan sampel ini menggunakan teknik proportional stratified random sampling. Sampel dikelompokkan dalam tiga strata, yaitu kelas 1, 2, dan 3. Untuk menentukan besar sampel setiap kelas meng- gunakan alokasi proporsional agar sampel yang diambil pun jumlahnya proporsional. Berdasar paparan Notoatmodjo (2005) untuk populasi kecil atau lebih kecil dari 10.000, maka diperoleh jumlah sampel 96 siswa untuk kelas 7, 97 untuk kelas 8, dan 97 untuk kelas 9 dengan total seluruhnya 290 siswa.

Alat ukur yang digunakan dalam penelitian ini berbentuk kuesioner yang diisi sendiri oleh responden. Kuesioner yang digunakan merupakan alat ukur yang disusun oleh Ervini Natasya (2014) berdasarkan teori Emotional Autonomy Scale dari Steinberg \& Silverberg (1986) dengan reliabilitas 0,932 menggunakan Cronbach's alpha melalui bantuan SPSS 20.0. Alat ukur ini terdiri dari 67 item yang diturunkan dari keempat dimensi yaitu de-idealized, parent as people, non-dependency, dan individuation. Kuesioner kemandirian emosional ini terdiri dari item positif dan negatif yang tersebar secara acak. Skala pengukuran yang digunakan adalah skala likert dengan rentang skala 1-4. Setiap item pernyataan yang ada di dalam alat ukur ini terdiri dari empat alternatif jawaban, yaitu Sangat Sesuai (SS), Sesuai (S), Tidak Sesuai (TS), dan Sangat Tidak Sesuai (STS). Pada alat ukur kemandirian emosional ini, data dari masing-masing subjek penelitian diolah dan hasilnya dikategorikan menjadi dua kategori, yaitu tinggi dan rendah (lihat tabel 1).

Tabel 1. Kategorisasi Skor Total Kemandirian Emosional pada Setiap Aspek

\begin{tabular}{lrrrrr}
\hline \multicolumn{1}{c}{ Dimensi } & $\begin{array}{c}\text { Jumlah } \\
\text { Item }\end{array}$ & $\begin{array}{c}\text { Skor } \\
\text { Min }\end{array}$ & $\begin{array}{c}\text { Skor } \\
\text { Maks }\end{array}$ & $\begin{array}{c}\text { Kategori } \\
\text { Rendah }\end{array}$ & $\begin{array}{c}\text { Kategori } \\
\text { Tinggi }\end{array}$ \\
\hline Total & 67 & 67 & 268 & $67-167$ & $168-268$ \\
$\begin{array}{l}\text { Non } \\
\text { dependency }\end{array}$ & 14 & 14 & 56 & $14-35$ & $36-56$ \\
$\begin{array}{l}\text { Individuation } \\
\begin{array}{l}\text { Parent as } \\
\text { People }\end{array}\end{array}$ & 16 & 16 & 64 & $16-40$ & $41-64$ \\
$\begin{array}{l}\text { De- } \\
\text { idealized }\end{array}$ & 15 & 15 & 60 & $15-45$ & $46-60$ \\
\hline
\end{tabular}

Berdasarkan kategori yang telah di paparkan, berikut merupakan penjelasan untuk setiap kategori:

1. Kemandirian emosional tinggi artinya adalah kemampuan remaja awal untuk tidak bergantung secara emosional kepada orang tua mereka dibandingkan ketika masa anak-anak dilihat berdasarkan empat dimensi kemandirian emosional.

2. Kemandirian emosional rendah artinya adalah ketidakmampuan remaja awal untuk tidak bergantung secara emosional kepada orang tua mereka dibandingkan ketika masa anak-anak dilihat berdasarkan empat dimensi kemandirian emosional.

Analisis statistik dilakukan dengan bantuan program SPSS 20.0 for Windows. Metode analisis menggunakan uji non parametrik (Mann-Whitney dan Kruskal Wallis) untuk melihat perbedaan signifikan kemandirian emosional ditinjau dari jenis kelamin, usia, urutan kelahiran, pola asuh, suku bangsa, tempat tinggal, pendidikan ibu, dan aktivitas ibu pada subjek penelitian 


\section{HASIL DAN PEMBAHASAN}

Setelah pengumpulan data dilakukan, terkumpul sampel sejumlah 290 siswa dengan karakteristik demografi seperti tergambar di tabel 2.

Tabel 2. Data Demografi Subjek Penelitian

\begin{tabular}{|c|c|c|c|}
\hline \multicolumn{2}{|c|}{ Data Demografi } & \multirow{2}{*}{$\begin{array}{r}\text { Frekuensi } \\
133\end{array}$} & \multirow{2}{*}{$\begin{array}{r}\text { Persentase } \\
45,9 \%\end{array}$} \\
\hline & Laki-laki & & \\
\hline 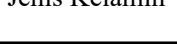 & Perempuan & 157 & $54,1 \%$ \\
\hline \multirow{5}{*}{ Usia } & 11 & 6 & $2,15 \%$ \\
\hline & 12 & 54 & $18,6 \%$ \\
\hline & 13 & 96 & $33,1 \%$ \\
\hline & 14 & 101 & $34,8 \%$ \\
\hline & 15 & 33 & $11,4 \%$ \\
\hline \multirow{4}{*}{$\begin{array}{l}\text { Urutan } \\
\text { Kelahiran }\end{array}$} & Sulung & 96 & $33,1 \%$ \\
\hline & Tengah & 75 & $25,9 \%$ \\
\hline & Bungsu & 101 & $34,8 \%$ \\
\hline & Tunggal & 18 & $6,2 \%$ \\
\hline \multirow{4}{*}{ Pola Asuh } & Authoritative & 257 & $88,6 \%$ \\
\hline & Authoritarian & 18 & $6,2 \%$ \\
\hline & Permissive & 9 & $3,1 \%$ \\
\hline & Neglected & 6 & $2,1 \%$ \\
\hline \multirow{6}{*}{ Suku Bangsa } & Sunda & 259 & $89,3 \%$ \\
\hline & Jawa & 19 & $6,6 \%$ \\
\hline & Batak & 7 & $2,4 \%$ \\
\hline & Minang & 2 & $0,7 \%$ \\
\hline & Nias & 1 & $0,3 \%$ \\
\hline & Betawi & 2 & $0,7 \%$ \\
\hline \multirow{3}{*}{$\begin{array}{l}\text { Tempat } \\
\text { Tinggal }\end{array}$} & Orang Tua & 281 & $96,9 \%$ \\
\hline & Nenek & 8 & $2,8 \%$ \\
\hline & Tante & 1 & $0,3 \%$ \\
\hline \multirow{7}{*}{$\begin{array}{l}\text { Pendidikan } \\
\text { Ibu }\end{array}$} & $\mathrm{SD}$ & 67 & $23,1 \%$ \\
\hline & SMP & 73 & $25,2 \%$ \\
\hline & SMA & 120 & $41,4 \%$ \\
\hline & D3 & 13 & $4,5 \%$ \\
\hline & $\mathrm{S} 1$ & 6 & $2,1 \%$ \\
\hline & $\mathrm{S} 2$ & 5 & $1,7 \%$ \\
\hline & $\mathrm{S} 3$ & 2 & $0,7 \%$ \\
\hline \multirow{7}{*}{$\begin{array}{l}\text { Aktivitas Ibu } \\
\text { (Pekerjaan } \\
\text { Ibu) }\end{array}$} & Buruh & 21 & $7,2 \%$ \\
\hline & Wiraswasta & 14 & $4,8 \%$ \\
\hline & Wirausaha & 9 & $3,1 \%$ \\
\hline & $\begin{array}{l}\text { Karyawan } \\
\text { Swasta }\end{array}$ & 13 & $4,5 \%$ \\
\hline & PNS & 9 & $3,1 \%$ \\
\hline & IRT & 223 & $76,9 \%$ \\
\hline & Meninggal & 1 & $0,3 \%$ \\
\hline
\end{tabular}

Kemandirian emosional tidak terjadi begitu saja. Terdapat beberapa faktor yang dapat mempengaruhi kemandirian emosional. Dalam penelitian ini, peneliti melakukan uji beda terhadap beberapa faktor yang mempengaruhi kemandirian emosional menurut Steinberg (2014) yaitu jenis kelamin, usia, budaya (suku bangsa), urutan kelahiran, tempat tinggal, pola asuh, pendidikan ibu, dan aktivitas ibu (pekerjaan ibu). Berdasarkan hasil rekapitu- lasi dan pemaparan data demografis tersebut, dapat dilihat bahwa siswa SMPN 1 Margaasih Kabupaten Bandung yang menjadi responden penelitian tersebar berdasarkan jenis kelamin, usia, suku bangsa, tempat tinggal, pola asuh, dan pendidikan ibu yang berbeda-beda.

Berdasarkan hasil pemaparan data (lihat tabel 3), diperoleh bahwa mayoritas siswa SMPN 1 Margaasih Kabupaten Bandung yaitu sebanyak 222 (77\%) dari 290 responden memiliki kemandirian emosional yang tinggi. Dari keempat aspek kemandirian emosional, terdapat dua aspek yang menunjang kemandirian emosional siswa SMPN 1 Margaasih Kabupaten Bandung tinggi, yaitu aspek de-idealized 158 (54\%) dan individuation 210 (72\%) siswa. Hal ini menunjukkan bahwa mayoritas responden penelitian ini memiliki kemampuan untuk mengatur dirinya sendiri dan tidak bergantung secara emosional dengan orang tua (Steinberg, 2014). Dengan kata lain, siswa SMPN 1 Margaasih Kabupaten Bandung mampu memandang orang tua bukan sebagai sosok yang paling tahu mengenai kehidupan dan perasaan remaja, mampu memandang dan berinteraksi dengan orang tua sebagai orang dewasa lainnya yang memiliki berbagai peran, dapat bergantung pada kemampuan dirinya sendiri tanpa mengharapkan bantuan dari orang tua ketika menyelesaikan masalahnya, dan memiliki sesuatu yang pribadi yang tidak selalu harus diketahui oleh orang tua dan dapat bertanggung jawab atas dirinya.

Aspek yang pertama yaitu de-idealized, sebanyak 158 (54\%) atau sebagian besar responden berada pada kategori tinggi. Artinya, siswa SMPN 1 Margaasih Kabupaten Bandung tidak lagi memandang orang tuanya sebagai sosok yang ideal yaitu, sosok yang paling mengetahui segala hal mengenai kehidupan dan perasaan remaja serta sebagai seseorang yang selalu benar (de-idealized). Menurut Steinberg (2014), cara pandang remaja mengenai orang tua merupakan proses yang akan terus berlanjut hingga remaja memasuki fase dewasa sehingga remaja memiliki pandangan yang lebih realistik terhadap orang tua. Apabila dilihat pada item-item alat ukur kemandirian emosional, dapat dikatakan bahwa siswa SMPN 1 Margaasih Kabupaten Bandung mampu memandang orang tua memiliki kesalahan dan keterbatasan serta mampu menentukan sendiri apa yang terbaik bagi dirinya misalnya menyadari bahwa orang tua pernah berbuat kesalahan atau berbohong kepada orang lain.

Aspek kedua yaitu individuation, sebanyak 210 (72\%) responden penelitian termasuk ke dalam kategori tinggi. Hal ini berarti responden mampu menunjukkan tanggung jawabnya secara verbal kepada orang tua, mampu bertanggung jawab atas dirinya, dan memiliki privasi yang tidak harus diketahui oleh orang tua, tidak menceritakan kepada orang tua semua hal mengenai dirinya termasuk yang sifatnya pribadi atau menjaga ruang pribadi (privacy) dari orang tua.

Menurut Zeman dan Shipman, dalam Steinberg (2002) menjaga jarak secara emosional dari orang tua me- 
Tabel 3. Gambaran Skor Total dan Setiap Aspek pada Dimensi Kemandirian Emosional

\begin{tabular}{cccccccccc}
\hline \multirow{2}{*}{$\begin{array}{c}\text { SKOR TOTAL KEMANDIRIAN } \\
\text { EMOSIONAL }\end{array}$} & \multicolumn{6}{c}{ SETIAP ASPEK KEMANDIRIAN EMOSIONAL } \\
\cline { 2 - 9 } & & \multicolumn{2}{c}{ De-idealized } & Parent as People & Non-Dependency & \multicolumn{2}{c}{ Individuation } \\
\hline Tinggi & Rendah & Tinggi & Rendah & Tinggi & Rendah & Tinggi & Rendah & Tinggi & Rendah \\
$77 \%$ & $23 \%$ & $54 \%$ & $46 \%$ & $8 \%$ & $92 \%$ & $44 \%$ & $56 \%$ & $72 \%$ & $28 \%$ \\
\hline
\end{tabular}

rupakan salah satu bagian dari proses individuation. Hal ini sesuai jika dilihat dari perkembangan sosialnya sendiri, remaja memiliki keinginan untuk memiliki privasi dari orang tua misalnya mengenai asmara, di mana remaja mulai tertarik dengan lawan jenis tetapi tidak ingin orang tua mengetahui hal tersebut. Proses individuasi bagi remaja ini dapat berkembang dengan baik apabila orang tua tidak menunjukkan kekuasaannya atas diri remaja sehingga remaja tidak merasa cemas dan takut pada orang tua ketika memiliki privasi (Hock, Eberly, et al., 2001; R. Ryan \& Lynch, 1989; Steinberg 2014).

Apabila dilihat pada item-item alat ukur kemandirian emosional, dapat dikatakan bahwa siswa SMPN 1 Margaasih Kabupaten Bandung memiliki privasi (sesuatu yang pribadi) yang tidak harus selalu diketahui orang tua, mampu menunjukkan tanggung jawabnya secara verbal kepada orang tua, dan mampu bertanggung jawab atas dirinya sendiri misalnya berani meminta maaf kepada orang tua jika lalai melaksanakan kewajiban.

Aspek ketiga yaitu parent as people menunjukkan bahwa sebagian besar responden sebanyak 268 (92\%) berada pada kategori rendah. Hal ini berarti, responden belum dapat memandang orang tua sebagai individu pada umumnya dan berinteraksi dengan orang tua tidak hanya sebagai orang tua dan anak tetapi juga hubungan antar individu. Hal ini tidak sesuai dengan teori menurut $\mathrm{McEl}-$ haney et al., 2009; Zimmer-Gembeck, Ducat, \& Collins, 2011 (dalam Steinberg, 2014) yang mengatakan bahwa aspek parent as people dapat dilihat dari hubungan interaksi remaja dengan orang tua, di mana semakin sering remaja berinteraksi dengan orang tua maka kemampuan remaja memandang orang tua sebagai individu biasa semakin baik, serta hal ini akan terus berkembang sampai remaja memasuki masa remaja akhir.

Apabila dilihat pada item-item alat ukur kemandirian emosional, dapat dikatakan bahwa siswa SMPN 1 Margaasih Kabupaten Bandung belum mampu memandang orang tua sebagai individu pada umumnya, selain sebagai sosok orang tua bagi remaja, menjelaskan keputusan yang diambil kepada orang tua selayaknya kepada orang dewasa lainnya, serta berdiskusi secara leluasa dengan orang tua tanpa adanya hambatan.

Menurut Steinberg (1995: 291) remaja pada tingkat SMP tampak mengalami kesulitan dalam memandang orang tua sebagaimana orang lain pada umumnya. Dalam analisisnya aspek kemandirian emosional ini sulit berkembang dengan baik pada masa-masa remaja. Hal yang mendukung bahwa aspek parent as people masuk ke dalam kategori rendah dapat dilihat berdasarkan pertanyaan terbuka dari data penujang, dilihat bagaimana pandangan remaja mengenai peran orang tua dalam kehidupan sosial. Hasil yang diperoleh menunjukkan bahwa, mayoritas responden belum bisa melihat orang tua memiliki peran lain sebagai individu biasa dalam kehidupan sosial, seperti peran sebagai anak, peran sebagai teman, peran sebagai adik/ kakak, dan peran sebagai tetangga.

Aspek keempat yaitu non-dependency, sebanyak 162 (56\%) responden atau dapat dilihat bahwa sebagian besar responden berada pada kategori rendah. Artinya, responden masih bergantung kepada orang tua dalam menyelesaikan masalah, masih mencari orang tua ketika sedang sedih serta meminta bantuan dalam mengambil keputusan, responden belum bisa bergantung pada dirinya sendiri. Apabila dilihat pada item-item alat ukur kemandirian emosional, dapat dikatakan bahwa siswa SMPN 1 Margaasih Kabupaten Bandung belum mampu mengatasi kesedihan dan gejolak perasaannya secara mandiri tanpa bantuan orang tua, mengambil keputusan untuk menyelesaikan masalahnya tanpa bergantung pada orang tua, serta menyampaikan gagasan/ide berdasarkan pendapatnya sendiri bukan pendapat orang tua.

Berdasarkan uji beda yang dilakukan peneliti, terdapat perbedaan yang signifikan pada kemandirian emosional berdasarkan usia responden penelitian yang berusia 12,13 , 14, dan 15 tahun. Jika dilihat dari hasil uji beda siswa SMPN 1 Margaasih Kabupaten Bandung, hasilnya memperlihatkan bahwa semakin meningkat usia remaja, semakin tinggi pula kemandirian emosionalnya. Hal ini didukung oleh teori yang menjelaskan bahwa kemandirian akan meningkat seiring bertambahnya usia pada periode remaja (W. A. Collins \& Steinberg, 2006, dalam Steinberg, 2014).

Hal ini juga sesuai dengan seiring bertambahnya usia tersebut, remaja cenderung memiliki pendapat yang berbeda dengan orang tua atau mereka tidak selalu setuju dengan orang tua (McElhaney et al., 2009; Zhang \& Fuligni, 2006, dalam Steinberg, 2014). Selain itu, remaja cenderung lebih mempertimbangkan risiko dan manfaat terkait dengan keputusan yang mereka buat dan mempertimbangkan konsekuensi jangka panjang dari keputusan yang mereka ambil (Crone \& van der Molen, 2007; Halpern-Ffelsher \& Cauffman, 2001; Steinberg, Graham et al., 2009, dalam Steinberg, 2014).

Peneliti selanjutnya melakukan uji beda kemandirian emosional berdasarkan jenis kelamin dan suku bangsa responden penelitian. Hasil penelitian tersebut menunjukkan tidak terdapat perbedaan yang signifikan antara kemandirian emosional dengan jenis kelamin responden penelitian. Menurut Steinberg dan Silverberg (1986), menyatakan bahwa perbedaan jenis kelamin dalam skor kemandirian emosional kurang kuat dibandingkan dengan perbedaan usia. 
Hal ini bertentangan dengan hasil-hasil penelitian sebelumnya, yaitu menurut Bancroftt, Carmody, dan Barcroft, 1996; Daddis dan Smenta, 2005, (dalam Steinberg, 2014), bahwa anak laki-laki diberi kebebasan lebih banyak tetapi anak perempuan kurang diberi kebebasan. Kemudian remaja perempuan memiliki perasaan lebih mandiri daripada remaja laki-laki (W. A. Collins \& Steinberg, 2006, dalam Steinberg, 2014), serta remaja perempuan juga lebih mampu melawan tekanan teman sebaya karena anak perempuan akan dewasa lebih awal secara psikososial daripada anak laki-laki (Steinberg \& Monahan, 2007, dalam Steinberg, 2014).

Tidak adanya perbedaan signifikan pada jenis kelamin dengan kemandirian emosional didukung oleh penelitian dari Wray-Lake, Crouter, \&McHale (2010) yang menjelaskan bahwa perbedaan kemandirian berdasarkan jenis kelamin bergantung pada sex role yang orang tua pahami, yaitu cara orang tua dalam mendidik anak yang relatif sama antara anak laki-laki dan perempuan serta bergantung pada kumpulan anak laki-laki dan perempuan di dalam keluarga.

Menurut Covey (2007:64), urutan kelahiran dan interpretasi terhadap posisi seseorang dalam keluarga berpengaruh terhadap cara seseorang berinteraksi. Urutan kelahiran, akan membentuk karakter tertentu. Feist \& Feist (2010 : 100) menjelaskan, anak sulung memiliki karakter selalu berkuasa, kecemasan tinggi, serta cenderung overprotektif. Anak tengah memiliki karakter kompetitif, minat sosial yang tinggi, dan mau bekerja sama. Anak bungsu kurang dewasa, sering kurang percaya diri, dan sering mengalami gangguan emosional.

Hal ini dapat mempengaruhi kemandirian yang dimiliki oleh remaja. Namun, pada uji beda urutan kelahiran, hasilnya menunjukkan tidak terdapat perbedaan yang signifikan pada urutan kelahiran dengan kemandirian emosional pada responden penelitian. Tidak adanya perbedaan yang signifikan tersebut disebabkan masih ada faktor lain yang perlu dipertimbangkan, seperti jarak usia antar anak. Jarak usia yang terlalu jauh dapat mengurangi pengaruh urutan kelahiran terhadap perkembangan kemandirian emosional (Santrock, 2014).

Selanjutnya, peneliti melakukan uji beda terhadap faktor tempat tinggal. Remaja yang tinggal terpisah dari orang tua namun tetap memiliki perasaan terikat dengan orang tua cenderung lebih mandiri (Steinberg, 2014). Namun, hasil penelitian yang didapatkan peneliti tidak sesuai dengan penelitian tersebut. Hasil penelitian menunjukkan bahwa tidak terdapat perbedaan yang signifikan pada kemandirian emosional dengan tempat tinggal responden penelitian. Hal ini dikarenakan tempat tinggal (dengan siapa tinggal) pada siswa SMPN 1 Margaasih Kabupaten Bandung homogen, 281 dari 290 responden tinggal dengan orang tua mereka, sehingga tidak seimbangnya proporsi setiap kelompok tempat tinggal yang ada pada siswa SMPN 1 Margaasih Kabupaten Bandung ini sehingga hasilnya tidak terdapat perbedaan yang signifikan pada kelompok tempat tinggal.
Terakhir, peneliti melakukan uji beda kemandirian emosional berdasarkan aktivitas ibu. Hasil penelitian menunjukkan bahwa tidak terdapat perbedaan yang signifikan antara kemandirian emosional berdasarkan aktivitas ibu. Hal ini bertentangan dengan penelitian yang dilakukan Lindgren, 1976; Burchinal \& Lovell, dalam Hoffman \& Nye (1984), (dalam Denrich dan Cindy 2003) yang mengatakan bahwa pola pengasuhan anak yang dilakukan pada ibu yang bekerja akan berbeda dengan ibu yang tidak bekerja.

Ibu yang bekerja, secara tidak langsung ,akan lebih banyak menekankan latihan kemandirian dan tanggung jawab terhadap pekerjaan rumah tangga. Hal ini dikarenakan aktivitas ibu (pekerjaan ibu) pada siswa SMPN 1 Margaasih Kabupaten Bandung homogen, 223 dari 290 responden adalah IRT (Ibu Rumah Tangga), sehingga tidak seimbangnya proporsi setiap kelompok aktivitas ibu yang ada pada siswa SMPN 1 Margaasih Kabupaten Bandung ini sehingga hasilnya tidak terdapat perbedaan yang signifikan pada aktivitas ibu. Kemudian penelitian ini tidak dapat digeneralisir ke SMP lain di Kabupaten Bandung maupun daerah lain.

\section{SIMPULAN}

Kemandirian emosional siswa SMPN 1 Margaasih Kabupaten Bandung berada dalam kategori tinggi. Artinya, mayoritas responden sudah tidak lagi bergantung secara emosional kepada orang tua, siswa SMPN 1 Margaasih Kabupaten Bandung mampu memandang orang tua bukan sebagai sosok yang paling tahu mengenai kehidupan dan perasaan remaja, dapat bergantung pada kemampuan dirinya sendiri tanpa mengharapkan bantuan dari orang tua ketika menyelesaikan masalahnya, mampu memandang dan berinteraksi dengan orang tua sebagai orang dewasa lainnya yang memiliki berbagai peran, dan memiliki sesuatu yang pribadi yang tidak selalu harus diketahui oleh orang tua dan dapat bertanggung jawab atas dirinya. Responden lainnya berada dalam kategori rendah. Artinya, masih terdapat siswa yang bergantung secara emosional kepada orang tuanya.

Penelitian ini menunjukkan bahwa sebagian kecil dari remaja masih belum mengembangkan kemandirian emosionalnya. Hal ini perlu menjadi perhatian pihak orang tua dan sekolah untuk dapat menjadi landasan penyusunan program pengembangan karena pentingnya membangun kemandirian emosional akan mempengaruhi pada tahapan berikutnya.

\section{DAFTAR PUSTAKA}

Anwar, N. A. (2015). Gambaran Kemandirian Emosional Remaja Usia 12-15 Tahun Berdasarkan Pola Asuh Authoritative. Universitas Padjadjaran, Psikologi. Sumedang: Universitas Padjadjaran.

Berk, L. E. (2005). Infants, Children, and Adolescents (5th ed.). Boston: Pearson Education. 
Budiman, N. (2010). Perkembangan Kemandirian pada Remaja. Jurnal Pendidikan, 3(1), 1-12.

Christensen, L. B. (2006). Experimental Methodology (10th ed.). Boston: Pearson Education.

Corey, G. (2009). Teori dan Praktek Konseling dan Psikoterapi. Bandung: Refika Aditama.

Feist, J., \& Feist, G. (2010). Teori Kepribadian (7th ed.). Jakarta: Salemba Humanika.

Friedenberg, L. (1995). Psychological Testing: Design, Analysis and Use. Boston: Allyn and Bacon.

Goodwin, C. J. (2010). Research In Psychology: Methods and Design (6th ed.). Hoboken: John Wiley \& Sons, Inc.

Hurlock, E. B. (2004). Developmental Psychology (6th ed.). New York: McGraw-Hill Education.

Kaplan, R. M., \& Saccuzzo, D. P. (2009). Psychological Testing: Principles, Applications, and Issues (9th ed.). Boston: Cengage Learning.

Kerlinger, F. N. (2006). Asas-Asas Penelitian Behavioral (3rd ed.). Yogyakarta: Universitas Gadjah Mada.

Mangkudilaga, E. N. (2014). Studi Komparatif Mengenai Kemandirian Emosional Pada Siswa SMP Yang Tinggal Di Asrama Dan Yang Tinggal Di Rumah Dengan Orang Tua. Universitas Padjadjaran, Psikologi. Sumedang: Universitas Padjadjaran.

Notoatmodjo, S. (2005). Metodologi Penelitian Kesehatan. Jakarta: Rineka Cipta.

Permana, M. S. (2011). PROGRAM BIMBINGAN DAN KONSELING UNTUK MENINGKATKAN KEMANDIRIAN SISWA . Universitas Pendidikan Indonesia, Bimbingan dan Konseling. Bandung: Universitas Pendidikan Indonesia.

Rice, F. P. (1996). The Adolescent: Development, Relationship, \& Culture (8th ed.). Boston: Allyn and Bacon.

Ryff, C. D. (1989). Happiness is Everything, or is it? Exploration on the Meaning of Psychological Well-Being. Journal of Personality and Social Psychology, 57(6), 1069.

Santrcok, J. W. (2014). Adolescence (11th ed.). New York: McGraw-Hill Education.

Santrock, J. W. (2014). Adolescence: Perkembangan Remaja (15th ed.). Jakarta: Erlangga.

Sarwono, S. W. (2000). Psikologi Remaja. Depok: RajaGrafindo Persada.

Steinberg, L. (1993). Autonomy, conflict, and harmony in the family relationship. In S. S. Feldman, \& G. R. Elliott, At the Treshold: The Developing Adolescent (pp. 255-276). Cambridge: Harvard University Press.

Steinberg, L. (1995). Adolescence. New York: McGrawHill Companies, Inc.
Steinberg, L. (2002). Adolescence (6th ed.). New York: McGraw-Hill Companies, Inc.

Steinberg, L. (2014). Adolescence (10th ed.). New York: Mc-Graw Hill Companies, Inc.

Steinberg, L. D., \& Silverberg, S. B. (1986). The Vicissitudes of Autonomy in Early Adolescence. Child Development, 57(4), 841-851.

Sugiyono. (2010). Metode Penelitian Kuantitatif. Kualitatif, dan R\&D. Bandung: Alfabeta.

Suryadi, D., \& Damayanti, C. (2003). Perbedaan Tingkat Kemandirian Remaja Putri yang Ibunya Bekerja dan yang Tidak Bekerja. Jurnal Psikologi, 1(1), $1-28$.

Widjaja, H. (1986). Hubungan antara Asuhan Anak dengan Ketergantungan Kemandirian. Universitas Padjadjaran, Pertanian. Sumedang: Universitas Padjadjaran.

Wray-Lake, L., Crouter, A. C., \& McHale, S. M. (2010). Developmental Pattern in Decision Making Autonomy Across Middle Childhood and Adolescence: European American Parents Perspective. Child Development, 81(2), 635-651. 